\title{
Survey of Basic Technical Skill for Futsal Male Student High School
}

\author{
Yogi Ferdy Irawan ${ }^{\text {a }}$, Indra Prayoto ${ }^{\text {b }}$ \\ ${ }^{a, b}$ Sports Education, Faculty of Teacher Training and Education, University of Ma'arif \\ Nahdlatul Ulama Indonesia \\ yogiferdian17@ yahoo.com ${ }^{\text {a }}$, berlianfcputrasadang@gmail.com ${ }^{\text {b }}$
}

\begin{abstract}
This research aims to find out: 1) Futsal playing skills of futsal extracurricular participants; 2) Basic techniques of playing futsal extracurricular participants. The sample in this study was an extracurricular futsal participant at Muhammadiyah Vocational School of Sadang which numbered 20 participants. This research design is a quantitative descriptive study with one variable without making comparisons and connecting with other variables. This study uses the FIK Jogja Futsal Skills Test instrument. The data analysis technique used is percentage, aims to collect data, present data and determine value, in addition to conclusions that can be made with reference to the standard of basic futsal skill level that has been determined. The results of the study can be concluded that the level of futsal playing skills of futsal athletes is sufficient with the consideration of the most frequency in the category enough with an average number of 76.61 at intervals $70-82$, namely middle value. The results of this study have implications: 1 . The emergence of coach awareness in improving the quality of exercises carried out, especially exercises related to the ability to play futsal. 2 . Encouraged coach to improve basic technical skills of playing futsal such as passing, dribble and shooting in students, as well as as an effort to achieve maximum results. This research can contribute information about the skill level of futsal athletes, so that it can be used as a consideration in compiling a training program or further research aimed at improving the futsal skills of futsal athletes.
\end{abstract}

Keywords: Basic Skills, Futsal, Extracurricular, Student High School

\begin{abstract}
Abstrak
Penelitian ini bertujuan untuk mengetahui: 1) Keterampilan bermain futsal peserta ekstrakurikuler futsal; 2) Teknik dasar bermain peserta ekstrakurikuler futsal. Sampel dalam penelitian ini adalah peserta futsal ekstrakurikuler di Muhammadiyah Vocational School of Sadang yang berjumlah 20 peserta. Desain penelitian ini adalah studi deskriptif kuantitatif dengan satu variabel tanpa membuat perbandingan dan terhubung dengan variabel lain. Penelitian ini menggunakan instrumen FIK Jogja Futsal Skills Test. Teknik analisis data yang digunakan adalah persentase, bertujuan untuk mengumpulkan data, menyajikan data dan menentukan nilai, di samping kesimpulan yang dapat dibuat dengan mengacu pada standar tingkat keterampilan futsal dasar yang telah ditentukan. Hasil penelitian dapat disimpulkan bahwa tingkat keterampilan bermain futsal atlet futsal cukup dengan pertimbangan frekuensi terbanyak dalam kategori yang cukup dengan jumlah rata- rata 76,61 pada interval 70-82, yaitu nilai tengah. Hasil penelitian ini berimplikasi: 1. Munculnya kesadaran pelatih dalam
\end{abstract}




\begin{abstract}
meningkatkan kualitas latihan yang dilakukan, terutama latihan yang berkaitan dengan kemampuan bermain futsal. 2. Mendorong pelatih untuk meningkatkan keterampilan teknis dasar bermain futsal seperti passing, dribble dan shooting pada siswa, serta upaya untuk mencapai hasil yang maksimal. Penelitian ini dapat memberikan kontribusi informasi mengenai tingkat keterampilan atlet futsal, sehingga dapat dijadikan pertimbangan dalam menyusun program pelatihan atau penelitian lebih lanjut yang bertujuan untuk meningkatkan keterampilan futsal atlet futsal sekolah menengah atas.
\end{abstract}

Kata kunci: Keterampilan Dasar, Futsal, Ekstrakurikuler, Sekolah Menengah Atas

\title{
1. Introduction
}

Futsal was first popular in Montevideo, Uruguay in 1930, by Juan Carlos Ceriani (Riyadi \& Doewes, 2017; Widiyono \& Mudiono, 2021). The uniqueness of futsal is gaining attention throughout South America, especially in Brazil. The skills developed in this game can be seen in the world-renowned style that Brazilian players show outdoors, on ordinary-sized pitches (Irawan \& Limanto, 2021; Sabdono, Sutapa, \& Phytanza, 2019). While Brazil continues to be the world's futsal center, the game is now played under the protection of the Federation International de Football Association worldwide, from Europe to Central and North America as well as Africa, Asia and Oceania (Burhaein, 2017; Sabdono et al., 2019; Sutopo \& Misno, 2021).

Futsal is a game of indoor football and has a smaller field size than the size of a football field (Azizah \& Sudarto, 2021; Riyadi \& Doewes, 2017). Futsal comes from the Spanish language, futbol (soccer) and sala (room), which when combined means to be "indoor football". Similar to football, futsal is a football game played by two teams, but the difference is futsal consist of five people each and has different rules of the game with football (Irawan \& Limanto, 2021; Widodo \& Najibuzzamzam, 2021). In addition to the five main players, each squad was also allowed to have a reserve player. Unlike other indoor soccer games, futsal pitches are restricted to lines, not nets or boards (Phytanza, Burhaein, Sukoco, \& Ghautama, 2018; Widiyono \& Mudiono, 2021).

Futsal entered Indonesia in 2002 after Indonesia was appointed by the AFC (Asian Football Confederation) futsal to host the "Futsal Asian Championship" tournament (Burhaein, Ibrahim, \& Pavlovic, 2020; Sabdono et al., 2019). At that time the tournament was broadcast live by one of the private television stations in Indonesia so that indonesian people can watch and get to know the sport of futsal (Ardian, Suharjana, \& Burhaein, 2019; Sabdono et al., 2019). Starting from the tournament, little by little the community began to accept and many entrepreneurs often held futsal tournaments in their employees' environment. To be able to achieve optimal futsal achievements need coaching. Coaching must start early, young age is very decisive towards achieving optimal achievement quality in the sport of futsal. Talented young athletes need to process with the coaching process scientifically, then emerge the achievements of athletes as much as possible at certain ages. In addition to coaching, to improve the achievement of playing futsal, many factors need to be considered such as infrastructure facilities, technical abilities, and the training process. Muhammadiyah Vocational School of Sadang is one of the vocational schools that pay attention to the interests and talents of learners in the field of futsal sports. Futsal activities are carried out outside of lesson hours and have 
been programmed by the school to become one of the extracurriculars. Before the futsal program is implemented, students are given information in advance about extracurriculars in the school, to provide opportunities for students to choose through questionnaires with several alternative choices of other activities. Extracurricular activities in the field of sports are volleyball, pencak silat and futsal.

The activity is programmed for all students of class $\mathrm{X}$ at Muhammadiyah Vocational School of Sadang, while for students of grades XI and XII are not allowed to participate in extracurricular activities because it is prioritized for academic achievement, considering students to concentrate more in preparation for the National Final Examination (UAN) or School Examination (US). Based on the results of observations, futsal extracurricular activities are held every Thursday and Saturday. 15.00 to $17.00 \mathrm{WIB}$ in the field. Facilities and infrastructure supporting extracurricular futsal include: futsal field, ball, mini wicket and cones. The number of balls is as many as 7 futsal balls, 2 mini wickets and cones as many as 30 pieces.

Based on preliminary studies conducted to see the urgency in the field. The results of the interview showed that Muhammadiyah Vocational School of Sadang had achievements that had been achieved, namely in 2019 to get the final opportunity in the Kabumen Regency Student Futsal League in 2020. This achievement is the best achievement ever obtained by the futsal team Muhammadiyah Vocational School of Sadang, Kebumen Regency. Futsal extracurricular participants from class X numbered 20 children in 2019/2020. All this is obtained from the results of the student's own choice given through the questionnaire. Students are given the questionnaire to choose for themselves what interests will be pursued by providing choices including extracurricular basketball, volleyball, laxation, music, and futsal. The expectation of students in following the extracurricular activities of futsal in school in addition to being able to channel talent, also to improve talent skills and achievement in playing futsal. To be able to play futsal well required a basic skill level of playing futsal, so that it is able to play for $2 \times 20$ minutes with the focus and technique of each student.

Based on the results of observations on the ground, researchers found a problem that among the many extracurricular activities, only extracurricular futsal has not been able to contribute satisfactory achievements both at the regional and national levels. The futsal activities in Muhammadiyah Vocational School of Sadang have not received good achievements and are different from the achievements that have been achieved by several high schools / vocational schools in Kabumen Regency. In addition, students of Muhammadiyah Sadang Vocational School are also not yet members of the Regency futsal team that is accommodated by the Kebumen Regency Futsal Association. This attracted the interest of the author to find out how much basic futsal technique skills, especially the extracurricular participants of futsal at Muhammadiyah Vocational School of Sadang. 1. Identification of Problems Based on the background of the problem can be identified various problems as follows: 1 . There has been no research on the futsal skills of the extracurricular participants of Muhammadiyah Vocational School of Sadang futsal. 2. Lack of achievement of Muhammadiyah Sadang Vocational School Students in the field of futsal sports. 3. There is no measure of how big the basic futsal technique skills of Futsal Extracurricular participants in Muhammadiyah Vocational School of Sadang. The goals to be achieved in this study are: 1.) To find out how much basic technical skills of futsal extracurricular participants at Muhammadiyah Vocational School of Sadang. 2) To motivate builders and participants after knowing the basic technical skills of futsal extracurricular participants at Muhammadiyah Vocational School of Sadang .3,) To explain to 
researchers and readers, especially futsal lovers about information on basic futsal engineering skills at Muhammadiyah Vocational School of Sadang.

\section{Research Methodology}

\subsection{Participant}

The subjects in this study were all the extracurricular futsal participants at Muhammadiyah Vocational School of Sadang. Participant determination technique using purposive sampling (Burhaein, Tarigan, Budiana, Hendrayana, \& Phytanza, 2021; Fraenkel, Wallen, \& Hyun, 2012; Phytanza, Burhaein, \& Pavlovic, 2021). The criteria are 1) Futsal Participants of Muhammadiyah Vocational School of Sadang; 2) Be active in futsal training and competitions, and; 3) Willing to be a participant in the study. Based on these criteria, participants can be determined precisely. The students who were participants in this study numbered 20 male students. Participants were in the age range of 15-18 $(\mathrm{M}=16.5 ; \mathrm{SD}=1.75)$.

\subsection{Research Design}

This research is a quantitative description study with one variable without making comparisons and connecting with other variables. Descriptive research is not intended to test a particular hypothesis, but simply describes "what it is" about something variable, symptom or circumstance (Arikunto, 2013; Phytanza \& Burhaein, 2020; Sugiyono, 2015). The method used in this study is a survey, the survey was conducted to find out the futsal playing skills of futsal extracurricular participants in Muhammadiyah Vocational School of Sadang.

\subsection{Research Instruments}

This Research Instrument uses the FUTSAL FIK Jogja Test quoted from the Futsal Playing Skills Test (Mahendra \& Saryono, 2012). Tests compiled to measure basic techniques of playing futsal include: passing, controlling, dribbling and shooting.

\subsection{Data Collection Techniques}

Research in the field of Muhammadiyah Vocational School of Sadang in September 2020 and using data collection techniques with survei.

Table 1. Futsal Basic Skills Data Collection Techniques

\begin{tabular}{|c|c|c|}
\hline $\begin{array}{ll}\text { No } & \text { Basic Futsal Skills } \\
\end{array}$ & Data collection techniques & Unit \\
\hline 1. Dribble & Dribble from post 1 to post 4 or the ball stops. & \multirow{5}{*}{$\begin{array}{l}\text { Units of } \\
\text { seconds are } \\
\text { calculated } \\
\text { from post } 1 \text { to } \\
\text { post } 4 \text { or the } \\
\text { ball stops. }\end{array}$} \\
\hline $\begin{array}{l}\text { 2. Passing without } \\
\text { Controlling }\end{array}$ & 10 times without control passing test & \\
\hline 3. Rotate 2 cones & $\begin{array}{l}\text { One cone rotates to the left, and one cone } \\
\text { rotates to the right }\end{array}$ & \\
\hline $\begin{array}{l}\text { 4. Passing with } \\
\text { Controlling }\end{array}$ & $\begin{array}{l}\text { Test passing control as many as } 10 \text { times right } \\
\text { foot and left foot }\end{array}$ & \\
\hline 5. Shooting on target & $\begin{array}{l}\text { Shooting at goal Using } 1 \text { time right foot or } \\
\text { left foot }\end{array}$ & \\
\hline
\end{tabular}




\subsection{Data Analysis Techniques}

Data analysis is the processing stage, after the research data is collected. This study is a descriptive research / overview that aims to provide a reality picture of the level of futsal playing skills of futsal extracurricular participants in Muhammadiyah Vocational School of Sadang. The data analysis technique used is percentage, aims to collect data, present data and determine value and in addition can be done the proposed meaning with reference to the standard of basic futsal skill level that has been determined.

In the FIK jogja futsal skills test made by Mahendra \& Saryono (2012) tidak disajikan dalam kategori. This researcher used a category owned by Anas Sudijono. Categorization based on mean and standard deviation. The results of the study are poured into 5 categories, namely very high, high, medium, low and very low (Fraenkel et al., 2012; Mohamad, Sulaiman, Sern, \& Salleh, 2015). The categorization can be described as Table 2.

Table 2. Statistical Formula

\begin{tabular}{ccc}
\hline No. & Formula & Category \\
\hline 1. & $\mathrm{X} \geq(\mathrm{M}+1,5 \mathrm{SD})$ & Very Good \\
\hline 2. & $(\mathrm{M}+1,5 \mathrm{SD}) \leq \mathrm{X}<(\mathrm{M}+0,5 \mathrm{SD})$ & Good \\
\hline 3. & $(\mathrm{M}-0.5 \mathrm{SD}) \leq \mathrm{X}<(\mathrm{M}+0,5 \mathrm{SD})$ & Medium \\
\hline 4. & $(\mathrm{M}-1,5 \mathrm{SD}) \leq \mathrm{X}<(\mathrm{M}-0,5 \mathrm{SD})$ & Low \\
\hline 5. & $\mathrm{X} \leq(\mathrm{M}-1,5 \mathrm{SD})$ & Vey Low \\
\hline
\end{tabular}

Furthermore, because this is an inverse data, the meaning of the category will be reversed as follows.

Table 3. Norms categorizing Basic Technical Skills playing Futsal

\begin{tabular}{ccc}
\hline No. & Formula & Category \\
\hline 1. & $\mathrm{M}-1,5 \mathrm{SD} \geq \mathrm{X}$ & Very Good \\
\hline 2. & $\mathrm{M}-1,5 \mathrm{SD}<\mathrm{X} \leq \mathrm{M}-0,5 \mathrm{SD}$ & Good \\
\hline 3. & $\mathrm{M}-0,5 \mathrm{SD}<\mathrm{X} \leq \mathrm{M}+0,5 \mathrm{SD}$ & Medium \\
\hline 4. & $\mathrm{M}+0,5 \mathrm{SD}<\mathrm{X} \leq \mathrm{M}+1,5 \mathrm{SD}$ & Low \\
\hline 5. & $\mathrm{M}+1,5 \mathrm{SD}<\mathrm{X}$ & Vey Low \\
\hline
\end{tabular}

\section{Results and Discussions}

\subsection{Results}

The first study result is in the form of original data from the measurement of basic technical ability to play futsal in athletes. The data can be seen in Table 4 .

Table 4. Data results from basic technical skills playing futsal

\begin{tabular}{cccccc}
\hline No & Participants & Class & Best & Seconds & Ranking \\
\hline 1 & Testee 1 & X TKRO & 105,45 & 65,45 & 5 \\
\hline 2 & Testee 2 & X TKRO & 103,12 & 63,12 & 2 \\
\hline 3 & Testee 3 & X AK & 115,34 & 75,34 & 9 \\
\hline
\end{tabular}




\begin{tabular}{cccccc}
\hline 4 & Testee 4 & X TKRO & 125,09 & 85,09 & 12 \\
\hline 5 & Testee 5 & X AK & 102.01 & 62,01 & 1 \\
\hline 6 & Testee 6 & X AK & 118,39 & 78,39 & 10 \\
\hline 7 & Testee 7 & X TKRO & 112,76 & 72,76 & 7 \\
\hline 8 & Testee 8 & X TKRO & 125,20 & 85,20 & 14 \\
\hline 9 & Testee 9 & X TKRO & 125,75 & 85,75 & 16 \\
\hline 10 & Testee 10 & X AK & 124,14 & 84,14 & 11 \\
\hline 11 & Testee 11 & X TKRO & 125,88 & 85,88 & 17 \\
\hline 12 & Testee 12 & X AK & 105,29 & 65,29 & 4 \\
\hline 13 & Testee 13 & X TKRO & 113,12 & 73,12 & 8 \\
\hline 14 & Testee 14 & X AK & 112,06 & 72,06 & 6 \\
\hline 15 & Testee 15 & X AK & 103,76 & 63,76 & 3 \\
\hline 16 & Testee 16 & X TKRO & 135,05 & 95,05 & 19 \\
\hline 17 & Testee 17 & X TKRO & 134,19 & 94,19 & 18 \\
\hline 18 & Testee 18 & X AK & 135,11 & 95,11 & 20 \\
\hline 19 & Testee 19 & X AK & 125,36 & 85,36 & 15 \\
\hline 20 & Testee 20 & X TKRO & 125,18 & 85,18 & 13 \\
\hline
\end{tabular}

This research is a quantitative descriptive study with one variable or single without making comparisons or connecting with other variables. From the results of research on the survey of basic skills of playing futsal, extracurricular futsal participants at Muhammadiyah Vocational School of Sadang need to be described the results of this study.

Table 5. Descriptive Statistics

\begin{tabular}{lccccc}
\hline \multicolumn{1}{c}{ Competence } & N & Min & Max & M & SD \\
\hline Futsal Skills & 20 & 62,01 & 95,11 & 78,56 & 10,72 \\
Valid N & & & & &
\end{tabular}

Description: $\mathrm{N}$ = Number of Students; Min= Minimum Value; Max= Maximum Value; $\mathrm{M}=$ Mean; $\mathrm{SD}=$ Standard Deviation

In descriptive statistics there is no significance test, no error level, because the researcher does not intend to make generalizations, so there are no generalization errors. Previously collected data is analyzed and verified and verified data 2 first. The next step is to calculate the score by changing the unit from minutes to seconds. In this study researchers measured the subject's futsal skills in seconds, excluding values below the second unit. This is done to facilitate calculations. Researchers calculated with Microsoft Excel media to make it faster and more efficient.

The results of the study obtained a maximum value (the longest) of 95.11, a minimum value (fastest) 62.01 and an average obtained of 76.61 and a standard deviation of 11.39. 
Furthermore, the data is categorized according to the formula that has been determined into 5 categories, namely Good Once, Good, Enough, Less, and Less Once. Table 7 is a calculation of the norms of the category of futsal playing skill levels of futsal extracurricular participants at Muhammadiyah Vocational School of Sadang.

Table 6. Normative Calculation of Futsal Extracurricular Participant Test Results

\begin{tabular}{lll}
\hline \multicolumn{1}{c}{ Formula } & \multicolumn{1}{c}{ Limitation } & \multicolumn{1}{c}{ Category } \\
\hline $\mathrm{M}-1,5 \mathrm{SD} \geq \mathrm{X}$ & $59 \geq \mathrm{X}$ & Very Good \\
\hline $\mathrm{M}-1,5 \mathrm{SD}<\mathrm{X} \leq \mathrm{M}-0,5 \mathrm{SD}$ & $59<\mathrm{X} \leq 70$ & Good \\
\hline $\mathrm{M}-0,5 \mathrm{SD}<\mathrm{X} \leq \mathrm{M}+0,5 \mathrm{SD}$ & $70<\mathrm{X} \leq 82$ & Medium \\
\hline $\mathrm{M}+0,5 \mathrm{SD}<\mathrm{X} \leq \mathrm{M}+1,5 \mathrm{SD}$ & $82<\mathrm{X} \leq 93$ & Low \\
\hline $\mathrm{M}+1,5 \mathrm{SD}<\mathrm{X}$ & $93<\mathrm{X}$ & Vey Low \\
\hline Information: & & \\
$\mathrm{X}=$ Score & & \\
$\mathrm{M}=$ Mear (Average) & & \\
$\mathrm{SD}=$ Standart Deviation & &
\end{tabular}

Referring to the categorization of the calculated tendencies, the distribution of the level of futsal playing skills of futsal extracurricular participants in Muhammadiyah Vocational School of Sadang based on the responses of research subjects can be known. Table 6 here is the distribution of futsal playing skill levels of futsal extracurricular participants at Muhammadiyah Vocational School of Sadang, Kebumen Regency.

Table 7. Frequency Distribution of Futsal Playing Skill Level

\begin{tabular}{clcc}
\hline Interval & \multicolumn{1}{c}{ Category } & Frequency & $\mathbf{\%}$ \\
\hline $59 \geq$ & Very Good & 0 & $0 \%$ \\
\hline $60-70$ & Good & 7 & $35 \%$ \\
\hline $69-82$ & Medium & 5 & $25 \%$ \\
\hline $81-93$ & Low & 5 & $25 \%$ \\
\hline $93<$ & Vey Low & 3 & $15 \%$ \\
\hline & Total & 20 & $100 \%$ \\
\hline
\end{tabular}

\subsection{Discussions}

Skill is a person's success in achieving effective and efficient goals determined by speed, precision, shape and ability to adjust (Ali, 2011; Burhaein, Tarigan, \& Phytanza, 2020; Sindik, 2014). Futsal is a team game played five against five people in indoor and outdoor courts. The game rolls faster from foot to foot with a small, flat and hard surface of the field in a given time and a team's victory is determined by the number of putting the most balls into the opponent's goal (Sabdono et al., 2019; Tarista \& Jayadi, 2017; Widiyono \& Mudiono, 2021). Futsal playing skills are an ability of speed, accuracy possessed by extracurricular futsal participants to dribble, passing and shooting quickly and precisely to create maximum results (goals) and each team can play fast from foot to foot to open space. 
Based on the results of futsal skills tests as many as 20 extracurricular participants of Muhammadiyah Vocational School of Sadang received the following data: 0 students or $0 \%$, The number of participants was declared Good: 7 students or 35\%, The number of participants was declared Sufficient: 5 students or 25\%, The number of participants was declared Less: 5 students or $25 \%$, The number of participants was declared Less Once: 3 students or $15 \%$. This is due to several factors that can affect the level of futsal playing skills of futsal extracurricular participants. The factors that can affect are: (1) facilities and infrastructure, (2) the level of futsal playing skills (dribble, passing and shooting) in each extracurricular participant, (3) training, and (4) the fitness level of extracurricular participants. An important factor in the achievement of one's futsal achievement is the mastery of futsal playing skills possessed by the player himself. Forms of futsal playing skills such as; Basic passing techniques, basic techniques of holding the ball (control), basic techniques of the hull (chipping), basic dribbling techniques (dribbling) and basic techniques of shooting the ball (shooting). To be able to master the basic skills of playing good futsal requires regular practice and discipline. Training can be done anywhere outside the school by utilizing the existing field.

In the implementation of futsal skills tests, the FIK Jogja futsal skill test test there are several categories that are tested, namely including dribble, passing without stopping (without controlling) 10 times right or left with a distance between the kick point and the wall which is 2 meters, passing with controlling 10 right and left and shooting 1 right and 1 left with a distance between the kick point and the wall which is 2.5 meters. Of these tests, futsal extracurricular participants are required to quickly complete a series of tests, because the best value can be obtained with the fastest time. So that it can allow extracurricular futsal participants to do tests quickly regardless of distance when kicking on a wall or wall.

One of the factors that can affect the results of futsal skill tests is practice. Exercise is an activity to improve skills by using various equipment in accordance with the goals and needs of the sport. The objectives and objectives of the exercise in general, among others: (1) improving basic physical qualities in general and thoroughly, (2) developing and increasing special physical potential, (3) adding and perfecting techniques, (4) developing and perfecting strategies, techniques, and playing patterns, and (5) improving the quality and psychic abilities of extracurricular participants in competing (Bompa \& Buzzichelli, 2019; Lloyd \& Oliver, 2012).

Thus the results of the overall research can be concluded that, the level of futsal playing skills of futsal extracurricular participants in Muhammadiyah Vocational School of Sadang is stated enough as many as 10 students (50\%). This means that the futsal skill level of the extracurricular futsal participants is between Good and Less while the average value of 76.61 at intervals $70-82$ is the middle value.

\section{Conclusions}

Based on the results of the study it can be concluded that the level of futsal extracurricular futsal playing skills in Muhammadiyah Vocational School of Sadang falls into the category quite based on table 7 regarding frequency distribution with the number of overall futsal extracurricular participants, namely 20 participants. The results of this study have implications for the emergence of awareness of builders in improving the quality of exercises carried out, especially exercises related to the ability to play futsal. The next implication is the triggering of coach to improve basic techniques of playing futsal such as passing, dribble and shooting in students, as well as as an effort to achieve maximum results. The limitations of this study are 1) The seriousness of each student in conducting a series of tests cannot be controlled; 2) The physical condition of the student before the test cannot be controlled so that it can affect the test; 3) The field (area) is not in accordance with the expected (limitations of the place), so the size does not match the instrument. This research can 
contribute information about the skill level of extracurricular futsal participants at Muhammadiyah Vocational School of Sadang, so that it can be used as a consideration in compiling a training program or further research aimed at improving the futsal skills of futsal extracurricular participants in Muhammadiyah Vocational School of Sadang.

\section{References}

Ali, A. (2011). Measuring Soccer Skill Performance: A Review Measuring soccer skill performance: a review. Scandinavian Journal of Medicine \& Science in Sport, 21(2), 170183. https://doi.org/10.1111/j.1600-0838.2010.01256.x

Ardian, R., Suharjana, S., \& Burhaein, E. (2019). Effect of progressive and repetitive part methods against the accuracy of kicking in football extracurricular students. ScienceRise, 1(7), 40-44. https://doi.org/10.15587/2313-8416.2019.174318

Arikunto, S. (2013). Prosedur Penelitian Suatu Pendekatan Praktik. Jakarta: Asdi Mahasatya. Azizah, A. R., \& Sudarto, E. P. (2021). Minat Mengikuti Ekstrakurikuler Bola Voli Siswa Smp

Negeri 3 Satu Atap Karangsambung Kecamatan Karangsambung Tahun Ajaran 2019/2020. JUMORA: Jurnal Moderasi Olahraga, 1(01), 35-44. https://doi.org/10.53863/mor.v1i01.132

Bompa, T. O., \& Buzzichelli, C. (2019). Periodization Theory and Methodology of Training (Sixth). United States.

Burhaein, E. (2017). Aktivitas Permainan Tradisional Berbasis Neurosainslearning Sebagai Pendidikan Karakter Bagi Anak Tunalaras. Jurnal SPORTIF: Jurnal Penelitian Pembelajaran, 3(1), 55. https://doi.org/10.29407/js_unpgri.v3i1.580

Burhaein, E., Ibrahim, B. K., \& Pavlovic, R. (2020). The Relationship of Limb Muscle Power, Balance, and Coordination with Instep Shooting Ability: A Correlation Study in Under-18 Football Athletes. International Journal of Human Movement and Sports Sciences, 8(5), 265-270. https://doi.org/10.13189/saj.2020.080515

Burhaein, E., Tarigan, B., Budiana, D., Hendrayana, Y., \& Phytanza, D. T. P. (2021). Physical Activity Level of Students with Disabilities during COVID-19 Pandemic. Jurnal Pendidikan Jasmani Dan Olahraga, 6(2), 19-21. https://doi.org/10.17509/jpjo.v6i2.38547

Burhaein, E., Tarigan, B., \& Phytanza, D. T. P. (2020). The experience and understanding of the K-13 curriculum implementation of Indonesian teachers of Adapted Physical Education (APE). International Sports Studies, 42(e), 29-42. https://doi.org/10.30819/iss.42-e.04

Fraenkel, J. R., Wallen, N. E., \& Hyun, H. H. (2012). How to design and evaluate research in education. New York: Mc Graw Hill.

Irawan, Y. F., \& Limanto, D. (2021). Pengaruh Kecerdasan Emosi dan Kesiapan Diri Terhadap Pertandingan Pada Pemain Walet Muda Futsal Academy Kebumen Tahun 2020. JUMORA: Jurnal Moderasi Olahraga, 1(01), 18-26. https://doi.org/10.53863/mor.v1i01.130

Lloyd, R. S., \& Oliver, J. L. (2012). The Youth Physical Development Model: A New Approach to Long-Term Athletic Development. Strength \& Conditioning Journal, 34(3), 
$61-72$.

Mahendra, A. S. D., \& Saryono. (2012). Tes Futsal FIK Jogja. Yogyakarta: FIK UNY.

Mohamad, M. M., Sulaiman, N. L., Sern, L. C., \& Salleh, K. M. (2015). Measuring the Validity and Reliability of Research Instruments. Procedia - Social and Behavioral Sciences, 204(November 2014), 164-171. https://doi.org/10.1016/j.sbspro.2015.08.129

Phytanza, D. T. P., \& Burhaein, E. (2020). The Effects of Tenure, Teacher Certification, and Work Motivation on Special Needs Teacher Performance. Universal Journal of Educational Research, 8(9), 4348-4356. https://doi.org/10.13189/ujer.2020.080962

Phytanza, D. T. P., Burhaein, E., \& Pavlovic, R. (2021). Gross Motor Skills Levels in Children with Autism Spectrum Disorder during the COVID-19 Pandemic. International Journal of Human Movement and Sports Sciences, 9(4), 738-745. https://doi.org/10.13189/saj.2021.090418

Phytanza, D. T. P., Burhaein, E., Sukoco, S., \& Ghautama, S. W. (2018). Life Skill Dimension based on Unified Sports Soccer Program in Physical Education of Intellectual Disability. Yaşam Becerileri Psikoloji Dergisi, 2(4), 199-205. https://doi.org/https://doi.org/10.31461/ybpd.453865

Riyadi, S., \& Doewes, R. I. (2017). The development of futsal learning model assure-based design of students of POK FKIP UNS. European Journal of Physical Education and Sport Science, 3(10), 347-355. https://doi.org/10.5281/zenodo.1066171

Sabdono, A., Sutapa, P., \& Phytanza, D. T. P. (2019). Development of skill training model attacking futsal by using small game-side 3 vs 3 to improve basic skill on high school student. Scientific Journal: ScienceRise, 7(60), 45-49. https://doi.org/10.15587/23138416.2019.174680

Sindik, J. (2014). The comparison of the psychological skills in sport trainers and recreational table tennis players. Fizicka Kultura, 68(2), 148-156. https://doi.org/10.5937/fizkul1402148s

Sugiyono. (2015). Metode Penelitian Pendidikan. Bandung: Alfabeta.

Sutopo, W. G., \& Misno. (2021). Analisis Kecepatan Tendangan Sabit Pada Pesilat Remaja Perguruan Pencak Silat Tri Guna Sakti Di Kabupaten Kebumen Tahun 2020. JUMORA: Jurnal Moderasi Olahraga, 1(01), 27-34. https://doi.org/10.53863/mor.v1i01.131

Tarista, R., \& Jayadi, I. (2017). Survei Keterampilan Teknik Dasar Permainan Sepakbola (Studi pada Ssb Rheza Mahasiswa Ku-14 Tahun). Jurnal Prestasi Olahraga, 1(1), 1-14.

Widiyono, I. P., \& Mudiono. (2021). Keterampilan Dasar Futsal Peserta Ektrakurikuler di SMK Ma'arif 1 Kebumen Tahun Ajaran 2019/2020. JUMORA: Jurnal Moderasi Olahraga, 1(01), 10-17. https://doi.org/10.53863/mor.v1i01.129

Widodo, P., \& Najibuzzamzam, A. (2021). Perbandingan Model Pembelajaran Daring Dan Tatap Muka Penjaskes Mts Darussa'adah Pada Masa Pandemi Tahun Ajaran 2019/2020. JUMORA: Jurnal Moderasi Olahraga, 1(01), 1-9. https://doi.org/10.53863/mor.v1i01.128 